\title{
Métodos de evaluación de las reacciones álcali-sílice en hormigones con áridos reciclados
}

\section{Evaluation methods of alkali-silica reaction in concrete with recycled aggre-gates}

\author{
Miguel Barreto Santos*, Jorge de Brito**1, António Santos Silva*** \\ * Instituto Politécnico de Leiria, PORTUGAL \\ **U niversidad Técnica de Lisboa, PO RTUGAL \\ ***Laboratorio Nacional de Ingeniería Civil, PO RTU GAL
}

Fecha de recepción: 22/ 06/2009 Fecha de aceptación: 20/ 07/ 2009 PAG. $141-152$

Resumen

\begin{abstract}
Las reacciones álcali-sílice son una de las causas químicas de la degradación de los hormigones con áridos pétreos (HAP) que comprometen su durabilidad. La introducción de áridos reciclados (AR) en los hormigones produce alteraciones en sus propiedades y diferencias en los resultados de los ensayos de evaluación de las RAS. Se encuentran en la bibliografía algunos cuidados en la evaluación de los AR y de los hormigo-nes con áridos reciclados (HAR) en cuanto a la RAS, así como propuestas de modificación de las metodologías de ensayo existentes. Existen propuestas de modificación del ensayo acelerado de mortero y hormigón con AR para acelerar las reacciones y recomendaciones para evitar altera-ciones en las características del AR grueso, durante la preparación de probetas. Algunos artículos recomiendan la pre-saturación del AR, debido a su absorción de agua, para evitar variaciones en los resultados de expansión de probetas de hormigón a edades prematuras. El presente artículo pretende describir sucintamente las características de los HAR y de las RAS presentando observaciones de la bibliografía en cuanto a los métodos de evaluación de las RAS en HAR y en HAP.
\end{abstract}

Palabras Clave: Hormigones con áridos reciclados, reacciones álcali-sílice, durabilidad, degrada-ción

Abstract

Alkali-silica reactions (ASR) are one of the causes of chemical degradation of concrete with natural aggregates (CNA) that compromise its durability. The introduction of recycled aggregates (RA) in concrete creates changes in their properties and differences in the results of the evalua-tion tests of ASR. Existing bibliography emphasizes special care in the evaluation of RA and concrete with recycled aggregate (CRA) for ASR and changes are proposed to the existing test methods. There are pro-posals to change the accelerated test of mortar and concrete with RA to accelerate the reactions and recommendations to prevent changes in the characteristics of the RA, during the preparation of samples. Some articles recommend the pre-saturation of the AR, due to its absorption of water, to avoid significant variations in the results of expansion of concrete samples from early ages. This article aims to briefly describe the characteristics of CRA and ASR presenting comments from existing bibliography to the evaluation methods of ASR in CRA and CNA.

Keywords: Concrete with recycled aggregates, alkali-silica reaction, durability, degradation

\section{Introducción}

El ataque por reacciones sulfáticas internas y por reacciones álcali-árido puede provocar la de-gradación del hormigón a través de las denominadas "reacciones expansivas de origen interna". Las reacciones álcalisárido (RAA) engloban las reacciones álcali-sílice (RAS), álcali-silicato y álcali-carbonato, aunque sean las RAS las que vienen presentando una mayor relevancia.

\section{Introduction}

The attack by internal sulfate reactions and by alkali-aggregate reactions may cause concrete degradation because of the so called "expansive reactions from internal origin". Alkali-aggregate reactions (AAR) include alkalisilica reactions (ASR), alkali-silicate and alkali-carbonate reactions, even though ASR are the most outstanding ones.

\footnotetext{
1 Autor de correspondencia / Corresponding author: E-mail: jb@civil.ist.utl.pt
} 
En los hormigones con áridos pétreos (HAP), la alteración de las propiedades del hormigón debi-do a las RAS origina principalmente la disminución de la capacidad de flexión y tracción, la re-ducción del módulo de elasticidad $y$, aunque en menor escala, de la resistencia a compresión. La reacción causa además otros efectos en el hormigón como son, por ejemplo, el aumento de volu-men o la fisuración de la superficie del hormigón, abriendo un camino preferente para la entrada de los agentes externos agresivos que aumentan la susceptibilidad de las estructuras a los proble-mas de corrosión de la armadura, ciclos hielo-deshielo, entre otros.

Entre las estructuras más afectadas por esta reacción deletérea se destacan las presas, los puentes, los muelles y los pavimentos de carreteras, aunque existan también registros del surgimiento de RAS en otros tipos de estructuras de hormigón.

Existe un conjunto de recomendaciones internacionales con relación a la temática de la prevención y mitigación de la reacción expansiva en los HAP. En Portugal, dichas recomendaciones se encuentran descritas en la Especificación E461 del Laboratorio $\mathrm{N}$ acional de Ingeniería Civil (LNEC) intitulada "Hormigones. Metodologías para prevenir reacciones expansivas internas" (LNEC E461, 2006).

La incorporación de áridos reciclados (AR) en hormigones altera sus características, obligando a algunos cuidados en los métodos convencionales de evaluación de las RAS. En los próximos ca-pítulos, se describen sucintamente las propiedades de los hormigones con áridos reciclados (HAR), la problemática de las RAS en HAP y algunas observaciones en cuanto a las metodologías de ensayo de las RAS en HAR.

\section{Hormigones con áridos reciclados}

Los AR tienen varias aplicaciones, como refieren Brito (2005), Carrijo (2005), Miranda (2000) y Hansen (1992), que incluyen utilizaciones en las capas de base y su-base de pavimentos de carre-teras 0 en terraplenes con características diversas que no implican una selección tan rigorosa de sus componentes. En aplicaciones más exigentes, como morteros u hormigones estructurales, es necesario tener un conocimiento más profundo de las potencialidades y limitaciones de Ios AR que serán incorporados en las mezclas.

La granulometría y el proceso de trituración del árido, dando formas y texturas a las partículas, influencian la resistencia mecánica, la trabajabilidad y el consumo de cemento en los HAR (Bri-to, 2005).
Changing the properties of concrete with natural aggregates (CNA) because of ASR, mainly reduces flexural and tensile capabilities, decreases the elastic modulus and at a minor scale reduces compression strength. The reaction also causes other effects in concrete such as, for example, the increase of volume or cracks on the concrete surface, which allow external aggressive agents to ingress which increase the susceptibility of structures to corrosion reinforcement effects or freezing thawing cycles, among others.

The most affected structures by this noxious reaction are the dams, the bridges, the piers, and the highway pavements, although there is evidence of ASR in other kind of concrete structures.

There is a set of international recommendations regarding the thematic of prevention and mitigation from the expansive reaction in CNA. Such recommendations are available from E461 Specification at the $N$ ational Laboratory of Civil Engineering (LNEC) in Portugal, under the title "Concrete. Methodologies to prevent internal expansive reactions (LNEC E461, 2006).

The use of recycled aggregate (RA) changes concrete properties, demanding special care on traditional ASR tests methods. The following chapters briefly describe the properties of concrete using recycled aggregate (CRA), the problems arising from ASR in CNA as well as some other remarks referred to ASR test methodologies in CRA.

\section{Concrete with recycled aggregates}

The RA have several applications, as referred by Brito (2005), Carrijo (2005), Miranda (2000) and $H$ ansen (1992). RA can be used in highways pavement base layer and sub-base layer or in landfills of a such diverse nature that a very rigorous selection of components is not required. The most demanding applications such as mortar and structural concrete require an expert knowledge about capabilities and restrictions of the RA to be included in the mixtures.

The grading and crushing process of grading and crushing aggregates, that provide shape and texture to particles, also influence mechanical resistance, workability and cement consumption in CRA (Brito, 2005). 
Se ha constatado, por análisis de la bibliografía, que las características del mortero adherido son la principal causa de la disminución de la resistencia mecánica de Ios AR. Alaejos y Sánchez (2004) afirman, por ejemplo, que no se deberían utilizar AR provenientes de hormigones con va-Iores de resistencia a compresión inferiores a 25 $\mathrm{MPa}$.

Las referencias bibliográficas relatan, en su generalidad, una disminución de la trabajabilidad del HAR tanto mayor cuanto mayor es la tasa de sustitución de áridos pétreos (AP) por AR, en parte debido a la mayor absorción de agua de los AR, como verificado en las campañas experimentales de Santos (2002), Matias y Brito (2005) y Evangelista (2007) para una relación agua/cemento (a/c) efectiva constante. Esta alteración en la propiedad del hormigón fresco puede ser atenuada, por ejemplo, según las recomendaciones de Alaejos et al. (2004), mediante la cuantificación de la cantidad adicional de agua a juntar al hormigón durante su producción, la presaturación de los áridos o la utilización de adyuvantes (materiales cementicios suplementarios 0 adiciones minera-les).

La diferencia entre la resistencia a compresión del HAR y la del HAP aumenta con el aumento de la clase de resistencia del hormigón. Sin embargo, manteniendo la curva granulométrica de los áridos y la trabajabilidad del hormigón fresco idénticas, la resistencia del HAR comparada con la del HAP viene presentando valores satisfactorios (Brito, 2005). No obstante, existen algunos condicionantes adicionales a tener en cuenta como, por ejemplo, el consumo de cemento, la tasa de sustitución, el porcentaje de áridos finos en la mezcla y el tipo de árido, la relación a/c y la uti-lización de adyuvantes. Cuanto a la resistencia a tracción, Brito (2005), en su lección de síntesis, considera que la diferencia entre los valores se mantiene con la introducción de $A R$ en el hormi-gón, aunque de manera menos acentuada que en la resistencia a compresión.

La rugosidad de los áridos es normalmente superior en los AR relativamente a los AP contribu-yendo para una mejora en la resistencia a la abrasión, aunque el comportamiento de los HAR y HAP con respecto a la abrasión pueda depender también de la relación a/c efectiva adoptada en cada uno, de la porosidad, de la irregularidad de la superficie de los áridos así como del contenido de ligante. Se registra en la bibliografía una tendencia para la disminución del módulo de elasti-cidad y un aumento de la retracción relativamente al HAP con el aumento de la tasa de sustitu-ción de AP por AR (Brito, 2005).
Bibliography analysis indicates that characteristics of adhered mortar are the main reasons of mechanical resistance decrease in RA. Alaejos and Sánchez (2004), for example state that RA coming from concrete having compression resistance value below $25 \mathrm{MPa}$, should not be used.

Bibliography references generally indicate that workability reduction of CRA is higher, as long as the replacement rate of natural aggregates $(\mathrm{NA})$ by recycled aggregates (RA) is also high. This is mainly because of the higher water absorption by RA, as proven in tests made by Santos (2002), Matias and Brito (2005) and Evangelista (2007) for a constant effective water/cement $(w / c)$ ratio. This change in the property of fresh concrete can be reduced, for instance, following recommendations from Alaejos et al. (2004). Those are the quantification of additional amount of water to put in concret during production, the aggregate pre-saturation or the use of admixtures (supplementary cementing materials or mineral addition).

Difference between compression resistance of CRA and CNA rises as per the increase of concrete type of strength. However by keeping the grading curve of the aggregate and the fresh concrete workability just identical, the resistance of CRA compared to the resistance of CNA happens to yield satisfactory values (Brito, 2005). However, there are some additional constraints to keep in mind such as, for example, the cement consumption, the replacement ratio, the fine aggregate percentage included in the mixture and the kind of aggregate, the ratio $\mathrm{w} / \mathrm{c}$ and the adjuvant utilization. As far as tensile resistance is concerned, Brito (2005), in is synthesis lesson, considers that value difference is still present when adding RA to concrete, however it is less prominent compared to compression resistance.

Aggregate roughness is normally higher in RA than in NA, contributing to a higher abrasion resistance, although CRA and CNA abrasion behavior may also depend on each effective $w / c$ ratio adopted, on the porosity, on irregular aggregate surface and also on the content of binder. Bibliography shows a trend of decreasing the elastic modulus and increasing CNA shrinkage by the replacement rate of NA by RA (Brito, 2005). 
La permeabilidad de los hormigones es uno de los factores comprometedores de su durabilidad, permitiendo el surgimiento y agravamiento de algunas causas de deterioración como la carbona-tación, el ataque por cloruros y el desarrollo de RAS. La porosidad de los HAR, como comentado por Levy (2001) en su estudio sobre la durabilidad de los HAR, contribuye para que estos hormi-gones estén más susceptibles a la influencia de los agentes externos.

\section{Las reacciones álcali-sílice}

Las condicionantes de la durabilidad del hormigón pueden tener origen química o física. Las causas químicas de la degradación del hormigón son (Santos Silva, 2007):

- ataque por el agua del mar;

- ataque por sulfatos;

- ataque por el agua dulce y medios ácidos;

- ataque bioquímico;

- corrosión de la armadura;

- reacciones expansivas internas.

Las RAS, que están englobadas en las reacciones expansivas internas del hormigón y que son del ámbito del estudio en este artículo, se definen como la reacción entre la solución alcalina y algu-nos minerales de sílice que, en presencia de agua, genera un gel expansivo. Para que la RAS ocurra es necesaria la presencia en simultáneo en el hormigón de contenidos su-ficientes en humedad, álcalis y áridos reactivos (Fernandes, 2005).

Una de las principales fuentes de suministro de álcalis es el cemento aunque, como también indi-ca el informe técnico TR3 (2003), cualquier fuente de sodio o potasio pueda ser una contribución para el desarrollo de la reacción. Así, la cantidad en álcalis del hormigón debe contabilizar tam-bién las diversas fuentes internas y externas que sean potenciales suministradoras de álcalis, con-cretamente los álcalis de los áridos.

El oxido de sodio equivalente $\left(\mathrm{Na}_{2} \mathrm{O}_{\text {eq }}=\mathrm{Na}_{2} \mathrm{O}\right.$ $+0.658 \times \mathrm{K}_{2} \mathrm{O}$ ) es utilizado, por convención, para indicar el contenido en álcalis del cemento Portland, siendo normalmente limitado, como forma de mitigar la RAS, a valores inferiores al 0,6\% (ASTM C150-02, 2003), si bien algunos autores (Stievenard-Gireaud, 1987; Prince y Perami, 1993), recomienden limites inferiores. Las recomendaciones más actuales recomiendan que el control del contenido en $\mathrm{Na}_{2} \mathrm{O}$ eq del hormigón sea igual a la suma del contenido en $\mathrm{Na}_{2} \mathrm{O}_{\text {eq }}$ de sus constituyentes,
Concrete permeability is one of the facts that affects its durability, allowing damage and aggravating of some degradation causes such as carbonation, chloride attacks and ASR development. The porosity on CRA, contributes to a higher exposure to foreign agents influence of this concrete, as indicated by (Levy 2001) on his CRA durability study.

\section{The alkali-silica reactions}

Constraints on the durability of concrete may have chemical or physical origin. Chemical facts for concrete degradation are (Santos Silva, 2007):

- Seawater attack;

- Sulfate attack;

- Fresh water and acid environment attacks;

- Biochemical attack;

- Reinforcement corrosion;

- Internal expansion reactions.

ASR, which is included in concrete internal expansion reactions, scope of this study are defined as the reaction between an alkaline solution and some silica minerals that in the presence of water generate an expansive gel. For ASR to develop, the simultaneous presence of appropriate content of moisture, alkalis and reactive aggregate will be required in the concrete (Fernandes, 2005).

O ne of the main alkali supply sources is cement although, any sodium or potassium source can also contribute to trigger the reaction, as indicated in the technical report TR3 (2003). Thus, the alkalis amount contained in the concrete must also register the different external and internal potential alkalis sources, specifically alkalis from aggregates.

The equivalent sodium oxide $\left(\mathrm{Na}_{2} \mathrm{O}_{\text {eq }}=\mathrm{Na}_{2} \mathrm{O}\right.$ $+0.658 \times \mathrm{K}_{2} \mathrm{O}$ ) is conventionally used to indicate the alkalis content in the Portland cement, being normally limited in order to mitigate ASR to values lower than $0.6 \%$ (ASTM C150-02, 2003), even though some authors recommend lower limits (Stievenard-Gireaud, 1987; Prince and Perami, 1993). The most recent recommendations suggest that the control of $\mathrm{N} \mathrm{a}_{2} \mathrm{O}_{\text {eq }}$ content in concrete must be equal to the addition of $\mathrm{Na}_{2} \mathrm{O}_{\text {eq }}$, content and 
con el límite de $3 \mathrm{~kg} / \mathrm{m}^{3}$, excepto para las estructuras vulnerables cuyo valor es aún menor.

El mecanismo reaccional de la RAS ha sido del ámbito de estudio de diversos investigadores co-mo Dent Glasser y Kataoka (1981a, b), Chatterji (1989), Hobbs (1988) entre otros. Las diversas contribuciones científicas han conducido a la explicación del mecanismo reaccional de la RAS actualmente para dos modelos distintos, el modelo topoquímico y el modelo de disolución - precipitación (Santos Silva, 2006). En el modelo topoquímico la reacción es descrita como siendo desarrollada en la superficie de los áridos reactivos, sin que necesariamente exista un traslado de especies reactivas del árido para la solución. En el modelo de disolución - precipitación la reac-ción es desarrollada en la solución intersticial después del cambio al estado iónico de las diversas especies reactivas. Las teorías de formación del gel sílice-alcalino y de su expansividad son ac-tualmente también encuadradas en estos dos modelos.

La expansividad del gel formado por el desarrollo de la RAS provoca la degradación del hormi-gón a través de diversos efectos mecánicos tanto para el material como para la estructura. Nor-malmente, la degradación del hormigón por RAS puede tardar algún tiempo en manifestarse y la sospecha de su existencia se acentúa con el surgimiento de fisuras, exudaciones, eflorescencias, pop-outs, descamaciones y expansión de la estructura. El diagnostico in situ es posteriormente confirmado a través del análisis microscópica en laboratorio.

La figura 1 ilustra algunas estructuras afectadas por RAS con fisuración típica de la reacción. components, limited to $3 \mathrm{~kg} / \mathrm{m}^{3}$, except for vulnerable structures whose value is even lower.

Reaction mechanism in ASR has been studied by several researchers as D ent G lasser and Kataoka (1981a, b), Chatterji (1989), Hobbs (1988) among others. At the present time, different scientific contributions have led to understand the reaction mechanism in ASR for two different models, the topochemical and the dissolution/precipitation model (Santos Silva, 2006). In the topochemical model, the reaction is described as being developed on the reactive aggregates surface without necessarily a movement of the aggregate reactive species to the solution. In the dissolution/precipitation model the reaction is developed in the interstitial solution after different reactive species have changed into ionic state. The formation theories for alkali-silica gel and its expansive properties are presently inserted in these two models.

The expansibility of gel produced by the ASR development, causes concrete degradation because of diverse mechanical effects to the material and to the structure. Normally, concrete degradation by ASR may take long before revealing itself. However, cracking, bleeding, efflorescence, pop-outs, delamination and structure expansion are the evidences of degradation. Subsequently an in-situ diagnosis is confirmed by means of microscopic examination in the laboratory.

Figure 1 illustrates some structures affected by ASR, showing the typical cracking of the reaction.
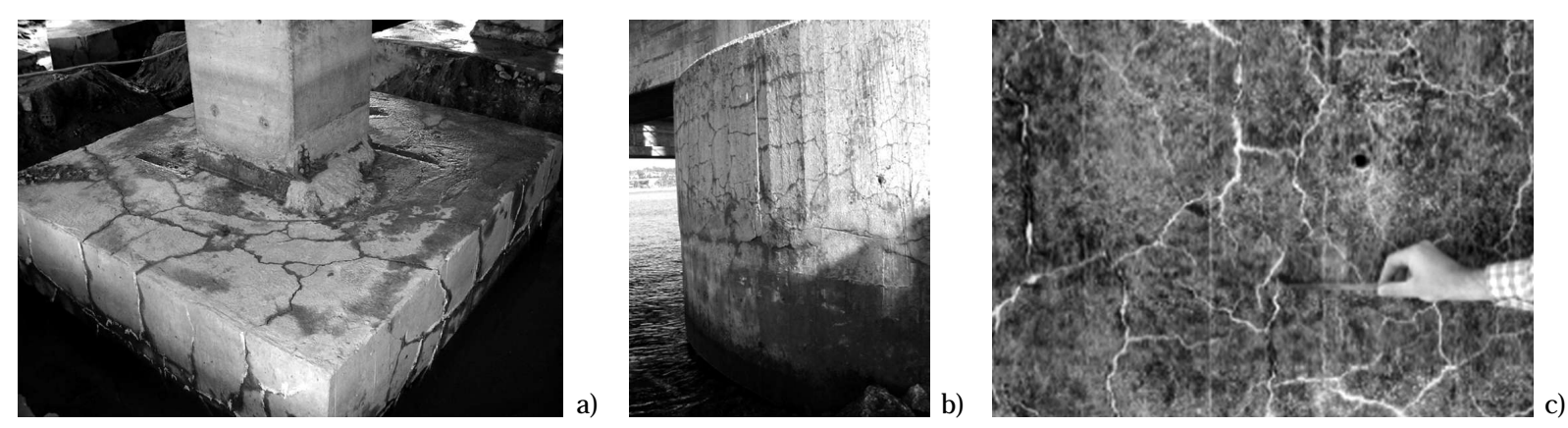

Figura 1. M anifestaciones macroscópicas de RAS. Fuente: figura a) (Pecchio et al., 2006); figu-ras b) y c) (Santos Silva 2007) Figure 1. ASR macroscopic revelation. Source: figure a) (Pecchio et al., 2006); figures b) and c) (Santos Silva 2007) 
No existe todavía una solución doradora de reparación de las estructuras afectadas por RAS, por lo que (Santos Silva, 2007), para asegurar la durabilidad de las estructuras frente a esta reacción deletérea, es necesario tomar medidas preventivas y seguir las recomendaciones en la elección de los materiales, sea mediante la utilización de áridos no reactivos a los álcalis, la reducción en alcalinidad de la solución intersticial del hormigón o el control de la humedad.

Sin embargo, existen algunos materiales que, introducidos en la mezcla del hormigón, o en algu-nos casos, en estructuras afectadas por RAS, pueden mitigar estas reacciones. Además de las adi-ciones minerales tipo II, las adiciones químicas a base de sales de litio son los materiales más ci-tados en la bibliografía.

\section{Investigación sobre métodos de evaluación de las RAS en HAR}

En el $11^{\text {th }}$ ICAAR, los investigadores Gress y Kozikowski (2000) presentaron un artículo en el que estudiaron alteraciones en las metodologías de diversos métodos de ensayo de las RAS en los HAP y en los HAR, para acelerar las reacciones y evitar largos periodos en espera de resultados. Estos autores justificaron la investigación con la necesidad de existir un ensayo acelerado, que evalúe el $A R$ y su incorporación en el HAR, para que la mezcla pueda ser rápidamente evaluada. Esta carencia surgió en la secuencia de la degradación de diversos quilómetros de un pavimento, en Estados Unidos, debido a la RAS. La posibilidad del reciclaje ser una opción para la rehabili-tación del pavimento condujo a la necesidad de estudiar la reactividad del AR y la continuación de la RAS en el HAR tras el aumento del contenido en álcalis.

Los ensayos realizados se basaron en los ensayos acelerados de mortero y de hormigón, de acuerdo con las normas ASTM C 1260 y ASTM C 1293 respectivamente, aunque utilizando prismas de hormigón con diferencias en la forma y en el modo de conservación. Los ensayos fueron acelerados, más allá de lo estipulado en dichas normas, a través de aumentos de temperatura, aplicación de energía de microondas, utilización de energía ultrasónica e incrementos del contenido en álcalis. El ensayo ASTM C 1260, por ejemplo, es rápido en evaluar los AP usando pequeñas probetas de $25 \times 25 \times 280 \mathrm{~mm}$, pero no fue empleado para evaluar los AR debido a las restricciones al tamaño máximo de los áridos en los pequeños moldes. Por eso,
There is no standard solution to repair the structures affected by ASR yet, so (Santos Silva, 2007) in order to guarantee the structures durability faced with this noxious reaction, it is necessary to take preventive measures and follow the recommendations in construction materials selection, by using non-reactive alkali aggregates, reducing interstitial solution alkalization of concrete and controlling moisture.

However, there are some materials that included in the concrete mixture, or in some cases, applied on a structure affected by ASR, may mitigate these reactions. A part from adding type II minerals, adding chemicals based on lithium salts are the most mentioned materials in the bibliography.

\section{Research on ASR evaluation methods for CRA}

At the $11^{\text {th }}$ ICAAR, the researchers Gress and Kozikowski (2000) introduced a study referred to methodology changes on different trial methods in ASR for CRA and CNA, in order to accelerate reactions and avoid long waiting periods for final results. These authors justified the research on the need to have an accelerated ASR testing method, to evaluate RA and its incorporation in CRA, so that the concrete mixture may be easily tested. This deficiency rose during the ASR degradation sequence of several kilometers of pavement in the U nited States. Recycling possibility as an option for pavement restoration, led to study RA reactivity and ASR prolongation in CRA after alkali content increased.

Trials performed were based on the accelerated mortar and concrete tests in accordance with ASTM C 1260 and ASTM C 1293 standards respectively, although using concrete prisms with in different shape and preservation conditions. The tests were accelerated far beyond standards, by increasing temperature, using microwave energy, using ultra-sonic energy and increasing alkalis contents. For example, the ASTM C 1260 is an effective tool for evaluating NA using $25 \times 25$ $x 280 \mathrm{~mm}$ little specimens, however this test was not used to evaluate RA due to maximum size restrictions of the aggregates in the for small specimens. Therefore, 
estos autores pro-pusieron que las dimensiones de las probetas de ensayo ASTM C 1260 fueran alteradas a prismas de $76.2 \times 76.2 \times 279 \mathrm{~mm}$. El ensayo ASTM C1293, semejante al AAR-3 de la RILEM, es consi-derado por estos autores el ensayo más adecuado para relacionar el comportamiento del hormigón in situ con el comportamiento en laboratorio. Aún así, dado que el ensayo tiene la duración de un año, Gress y Kozikowski (2000) proponen modificaciones al ensayo, en concreto, el empleo de temperatura más elevada y diferentes condiciones de humedad con las probetas sellados en vacuo en un plástico con agua, intentado así obtener resultados de expansión correlacionadles estadísti-camente con el ensayo ASTM C 1293, pero en menos tiempo.

En la campaña experimental utilizaron AR gruesos provenientes del hormigón con RAS del pavimento reciclado, AP utilizados en el hormigón de origen (HO) del pavimento y AP finos ino-cuos. Los resultados del ensayo modificado ASTM C 1260 con alteraciones en la forma de las probetas (sólidos, con agujeros, con recortes laterales, entre otros) y el contenido de álcali, figura 2, muestran que el AR presenta una expansión menor que el $\mathrm{AP}$, utilizando un cemento con $\mathrm{Na}_{2} \mathrm{O}_{\text {eq }}$ de $1.15 \%$, siendo justificado por estos autores con la menor reactividad del AR por uni-dad de volumen y su mayor porosidad para contención del gel sílice-alcalino sin expandirse. Se verifica, de esta manera, que el HAR se expande menos que el HAP, aunque ocurra lo contrario con el aumento de álcalis. the authors suggested increasing specimen sizes of ASTM C1260 test up to $76.2 \times 76.2 \times 279 \mathrm{~mm}$. ASTM C1293 test, similar to RILEM AAR-3, is considered by the authors as the most adequate test to relate in situ concrete behavior to lab concrete behavior. Since this test yields results only after a year, Gress and Kozikowski (2000) suggested some modifications such as increasing the maximum temperature, using different moisture conditions with concrete samples sealed in evacuated plastic bags containing water, in order to obtain correlated expansion results statistically comparable to ASTM C 1293 test, in a shorter periods.

For the experimental trial, the following aggregates were employed: coarse RA coming from concrete from a recycled pavement affected by ASR; NA used in the original concrete $(O C)$ of the pavement; and innocuous fine NA. The modified ASTM C 1260 test results using modified specimens (solids, with holes, with sides cut, among others) and alkali content, figure 2, indicate that the RA shows a minor expansion than NA, when employing $\mathrm{Na}_{2} \mathrm{O}_{\text {eq }}$ cement at $1.15 \%$. thus the authors justify the RA minor reactivity per volume unit and the higher porosity capability to avoid alkali-silica gel without expansion. Therefore, this test confirms that CRA has a minor expansive reaction than CNA, although the contrary occurs upon alkalis increase.

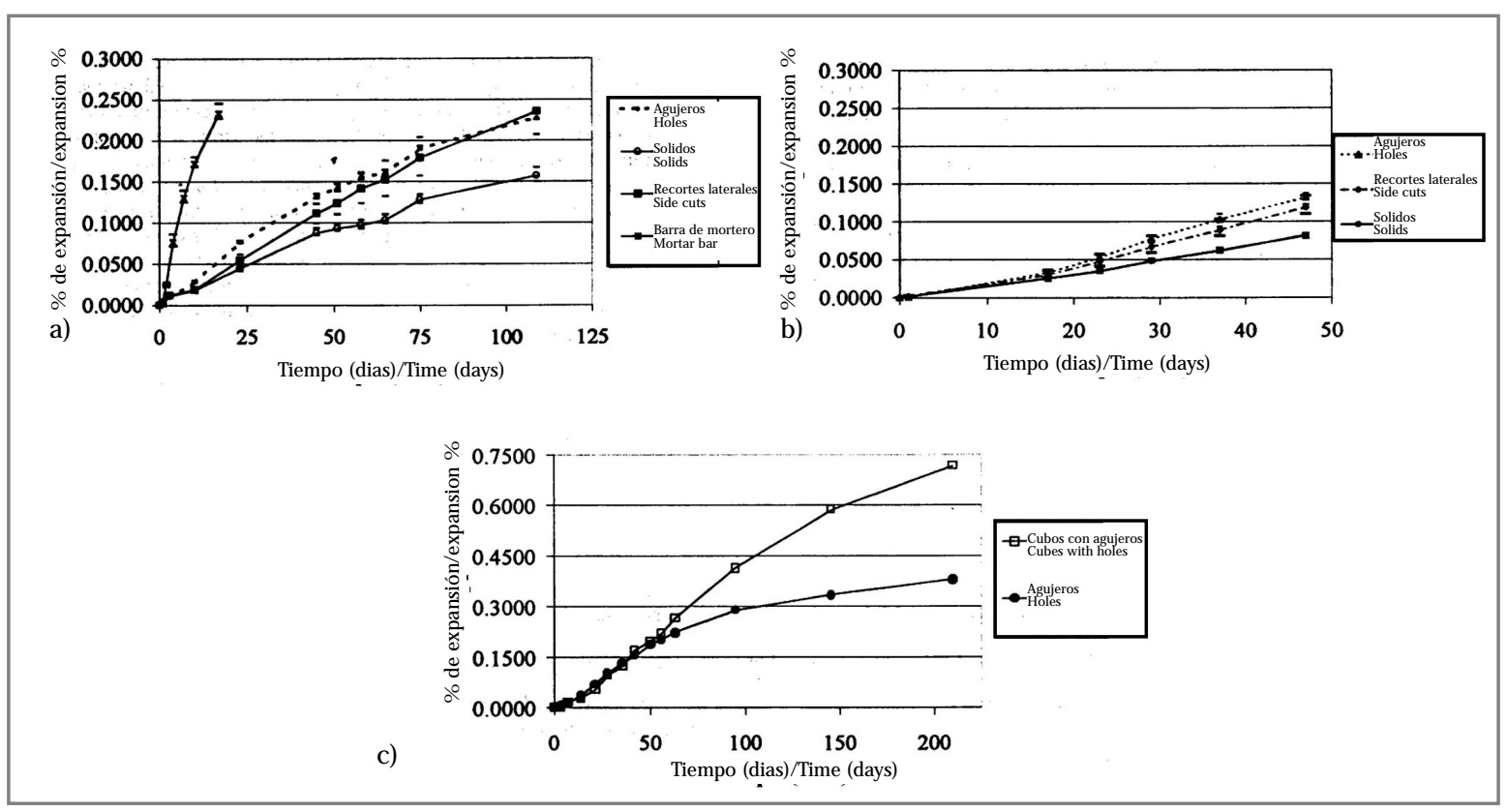

Figura 2. Resultados del ensayo ASTM C1260 modificado con (A) AP, (B) AR y $1.15 \%$ de $\mathrm{Na}_{2} \mathrm{O}_{\text {eq }}$ (C) AR y $1.37 \%$ de $\mathrm{Na}_{2} \mathrm{O}_{\text {eq }}$ (Gress y Kozikowski, 2000)

Figure 2. Results from ASTM C1260 modified test using (A) NA, (B) RA at $1.15 \%$ of $\mathrm{Na}_{2} \mathrm{O}_{\text {eq }}$

(C) RA at $1.37 \%$ of $\mathrm{Na}_{2} \mathrm{O}_{\text {eq }}$ (Gress and Kozikowski, 2000) 
Gress y Kozikowski observaron aún una buena correlación entre los resultados obtenidos en los ensayos modificados ASTM C 1293 y en los ensayos efectuados con energía de microondas. Concluyeron que las alteraciones introducidas en los ensayos ASTM C 1260 y ASTM C 1293 aceleraron efectivamente la RAS. Igualmente el ensayo de energía de microondas produjo efectos en el desarrollo acelerado del fenómeno expansivo. El análisis de ensayos modificados y la investigación de la RAS en HAR fueron del ámbito del estudio de Scott (2006). Este autor trabajó en la mitigación de la RAS en HAR investigando la reactividad de los HAR con AR de hormigón que había exhibido degradación debido a la RAS. Investigó también la hidratación inicial de los H AR y los resultados de las modificaciones intro-ducidas en Ios ensayos ASTM C 1260 y ASTM C 1293. En su revisión bibliográfica, refiere la escasa información existente sobre la RAS en los HAR, aunque en la que pudo consultar, sea re-comendado que se efectúen ensayos previos de reactividad a la RAS en los $A R$. Con relación al origen del AR y a la RAS, para Scott (2006), o el AR proviene de un hormigón con degradación por RAS, o entonces de un hormigón donde no se observó cualquier indicio de esta reacción dele-térea. Así, en el caso de que el HAR contenga AR de hormigón que haya estado sujeto a degradación por RAS, ésta pueda ahora no ocurrir al haberse extinguido en el HAP de origen. Por otro lado, puede nunca haber ocurrido por falta de condiciones ideales para su desarrollo y surgir aho-ra en el HAR si dichas condiciones son halladas. Puede también pasar que el AR utilizado pro-venga de un hormigón que haya reaccionado solo parcialmente, pudiendo en este caso ocurrir de inmediato la degradación debido a la RAS en el nuevo HAR, lo que puede significar la disminu-ción de la vida útil de la estructura. Este mismo investigador refiere además otras condiciones que pueden influir en la degradación del HAR debido a la RAS por incorporación de $A R$ de hor-migón que reaccionó solo parcialmente, como:

- la variación del valor del pH, por ejemplo, en el caso de que el $\mathrm{pH}$ del HAP tenga valores no compatibles con la RAS puede después, cuando se incorpore el $A R$ de hormigón en una mez-cla en la que el pH sea elevado, desarrollar RAS;

- el proceso de reciclaje y alteraciones en el medio, por ejemplo, del HAP en que las RAS no ocurrieron por falta de condiciones favorables, puede accionar las reacciones expansivas;
Gress and Kozikowski observed a good correlation between results obtained from modified ASTM C 1293 tests and the results obtained with microwave energy tests. They concluded that alterations applied to the ASTM C 1260 and ASTM C 1293 tests actually accelerated the ASR. The tests employing microwave energy also caused effects on the accelerated expansive phenomenon. The analysis from modified tests and the research on ASR in CRA were studied by Scott (2006). The author studied the ASR mitigation in CRA researching the CRA reactivity using concrete RA that presented degradation due to ASR. He also researched initial hydration moisture existing in CRA, and the results from modified ASTM C 1260 and ASTM C 1293 tests. In its bibliografhic research, he said that he has found little available information about ASR in CRA however, he found some recommendations to develop previous reactivity tests on ASR in RA. Regarding the RA origin and the ASR, Scott (2006) concluded that either the RA comes from a concrete with ASR distress, or from concrete where signs of this noxious reaction was not noticed. Thus in the case when the CRA contains RA that had been exposed to degradation by ASR, this reaction may not develop because it has been extinguished in the original CNA. On the other hand, the reaction could have never been developed because the ideal conditions to expand were not available, and may appear in the CRA if such conditions are present. It may also happen that if the employed RA comes from a partial reactive concrete, then degradation by ASR may develop immediately in the new CRA, leading to a reduction in structure lifetime. The same author refers to some other conditions causing degradation in CRA due to ASR, when using RA from concrete that reacted only partially, such as:

- For instance, $\mathrm{pH}$ value variation. When the $\mathrm{pH}$ of CNA does not have compatible values with ASR, if CRA is incorporated in a mix having a high $\mathrm{pH}$ value, then ASR may develop;

- The recycling process and environmet alterations for instance in the CNA where ASR has not developed due to lack of favorable conditions, may initiate expansive reactions; 
- Ios álcalis presentes en el gel sílice-alcalino de los AR de hormigón en el que ocurrieron las RAS pueden ser prejudiciales en el HAR ya que pueden contribuir para el nuevo desarrollo de las RAS;

- Ios álcalis del cemento y del AR pueden causar un aumento del pH en el HAR que puede ser más agresivo que el del $\mathrm{HO}$ en que el cemento era la única fuente de álcalis.

En la campaña experimental, Scott (2006) utilizó cemento de elevado contenido en álcalis y, co-mo áridos gruesos, un árido de control de Blue Rock y un AR de hormigón de un pavimento con AP de Blue Rock, también utilizado por Li (2005) en su trabajo, conocidos por su reactividad. Utilizó una arena no reactiva como AP fino y un AP grueso calizo, que sirvió de control para verificar si, además de los áridos gruesos reactivos, algún otro material contribuía para la RAS. Aplicó, para evaluación de la reactividad del material los ensayos ASTM C 1260 y ASTM C 1293. Asimismo, estudió también ensayos alternativos para acelerar la obtención de resultados, modificando las dimensiones de las probetas, introduciendo corriente eléctrica en las probetas de hormigón y variando las condiciones de humedad y temperatura de los ensayos. Dichas alteracio-nes tuvieron como base los trabajos de Kozikowski (Gress y Kozikowski, 2000; Kozikowski, 2000).

La utilización del ensayo ASTM C 1260 para el AR es comentada por Scott (2006), refiriendo que la reducción del tamaño de las partículas de AR para incorporación en la mezcla de mortero provoca la pulverización de la matriz de los áridos. El proceso de pulverización rompe el AR di-vidiendo el árido en AP y en mortero adherido, no ensayando el AR como conjunto. Este investi-gador examinó la reactividad del AP contenido en el $A R$, tras la separación del mortero adherido, mediante el ensayo ASTM C 1260. Las alteraciones al ensayo de la barra de mortero ASTM C 1260 consistieron en la sustitución de la barra de mortero por prismas de hormigón utilizados en el ensayo ASTM C 1293, pero utilizando las condiciones del ensayo ASTM C 1260, excepto en el valor limite de expansión que fue alterado de 0.10 para $0.04 \%$ a los 28 días. Analizó también la influencia de la sustitución de la barra de hormigón por un cubo con agujeros laterales, que facili-ta la entrada de la solución de $\mathrm{NaOH}$, aumentando de esta manera la cinética de las reacciones. En el ensayo de prismas de hormigón, preconizado por la norma ASTM C 1293, este autor introdujo alteraciones en las dimensiones de las probetas,
- Alkalis contained in the alkali-silica gel of the RA that had developed ASR may become harmful for CRA since they may contribute to a new ASR development;

- Cement and RA alkalis may increase the pH in CRA thus becoming more aggressive than $\mathrm{OC} \mathrm{pH}$ where the cement was the only alkalis source.

During the experimental campaign, Scott (2006) used cement with high alkalis contents and, as coarse aggregate, a Blue Rock control aggregate and a RA concrete from pavement containing NA from Blue Rock, well known as reactive agents also used in studies by $\mathrm{Li}$ (2005). The author used non-reactive sand as fine NA and limestone coarse NA, that helped to control and checked if, besides reactive coarse aggregates, some other material contributed to ASR. For the evaluation of reactive material, he applied the ASTM C 1260 and ASTM C 1293 tests. $\mathrm{He}$ also studied alternative tests to accelerate the results by modifying specimens dimensions, applying electric current on the concrete specimens and changing moisture and temperature conditions in such tests. Such alterations were based on the studies made by Kozikowski (Gress and Kozikowski, 2000; Kozikowski, 2000).

The use of ASTM C 1260 test for RA is commented by Scott (2006), referring indicating that size reduction of RA particles to be included in the mortar mixture causes the pulverizing of matrix aggregates. The pulverizing process crushes the RA separating the NA from adhered mortar, not testing the RA as a whole. The author examined the NA reactivity content in RA, after separating adhered mortar, by using the ASTM C 1260 test. The alterations to mortar bar method ASTM C 1260 consisted of replacing the mortar bar by concrete prisms used for the ASTM C 1293 test, but maintaining the conditions of ASTM C 1260 test, except for the expansion limit value that was modified from 0.10 to $0.04 \%$ at 28 days. He also analyzed the influence of replacing a concrete bar by a cube with side holes, which facilitate the $\mathrm{NaOH}$ solution penetrability, thus increasing kinetic reactions. For the concrete prisms test specified encouraged by ASTM C 1293 standard, the author made some modifications as far as specimen dimensions are concerned 
utilizando también cubos con agujeros late-rales pero sellados en vacuo en un plástico, uniformizando la distribución de la humedad.

Considerando que la protección catódica del acero, aunque protegiendo la armadura, promueve las RAS, Scott (2006) estudió también un método de acelerar la reacción para la obtención de re-sultados más expeditos a través del pasaje de corriente eléctrica - Figura 3. and he also used plastic vacuum sealed cubes with side holes, standardizing moisture distribution.

Considering that cathodic protection of steel promotes the ASR, though protects the reinforcement, Scott (2006) also studied a method to accelerate the reaction and get expedite results by passing electric current - Figure 3.

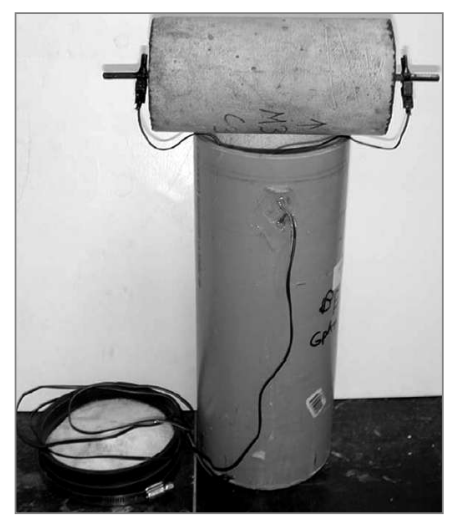

Figura 3. Ensayo de expansión con introducción de corriente eléctrica (Scott, 2006) Figure 3. Expansion test by passing electric current (Scott, 2006)

Scott (2006) en los ensayos de expansión observó que los HAR producidos tenían una elevada expansión inicial, que atribuyó a la absorción de agua de la mezcla durante la hidratación inicial de hormigón. Así, como también referido por Li (2005), presaturó los AR antes de su introduc-ción en las mezclas testadas, rellenando sus poros y asumiendo que de esta manera eliminaría las expansiones iníciales. Colocó los AR de hormigón en agua durante 48 horas y utilizó el agua de la pre-saturación para introducir en la mezcla, evitando la pérdida de álcalis. Experimentó tam-bién, en otro conjunto de AR, la saturación por vacuo, de forma a cuantificar solamente las ex-pansiones debidas a la RAS. Con las metodologías descritas, observó el efecto de algunas adicio-nes minerales, como cenizas volantes, escoria de alto-horno y sílice de humo, tal como el efecto de cemento de bajo contenido en álcali y la introducción de nitrato de litio en la mitigación de la RAS en los HAR. De estas estrategias verificó que únicamente el cemento de bajo contenido en álcalis, $55 \%$ de escorias de alto-horno, $25 \%$ de cenizas volantes o $100 \%$ de nitro de litio, fueron efectivos en la mitigación de la RAS, aunque tuvieran que ser considerados los procedimiento de preparación inicial de losáridos. Confirmó también el mayor contenido en álcalis solubles exis-tente en el AR de hormigón estudiado, con relación al AP de control, que atribuyó a la fracción de mortero del AR.
Scott (2006) observed from expansion tests that CRA produced had a high initial expansion, wich he attributed to the water absorption by the concrete mixture during the initial concrete hydration process. Thus, in accordance with Li (2005), the author pre-saturated the RA before adding them to the test mixes, by filling the pores and assuming that initial expansions would be avoided. The RA concrete was placed under water during 48 hours and water from pre-saturation was added to the mixture, thus avoiding loss of alkali. He also applied vacuum saturation in other RA set, in order to test expansions from ASR only. Using the methodologies described, the author observed the effect of some mineral additions, such as fly ash, blast furnace slag and silica fume, as well as the effect of using low alkali content cement, and the addition of lithium nitrate to mitigate ASR in CRA. It was verified that only low alkali content concrete, $55 \%$ of blast furnace slag, $25 \%$ of fly ash or $100 \%$ of lithium nitrate, were effective in ASR mitigation, even though initial preparation proceedings of aggregates also had to be considered. The author also confirmed the highest content of soluble alkalis existing in the concrete RA, in relation to the control $N A$, wich was attributed to the mortar fraction in RA. 
En sus conclusiones, este investigador considera que los ensayos a la RAS en AR de hormigón deberían ser enfocados en las características del material, incluyendo las tasas de absorción, de fracción de mortero y de álcalis libres. Comenta aún que los resultados de las alteraciones de los ensayos que efectuó, aunque proponiendo en algunos casos la continuación del seguimiento, mostraron correlaciones satisfactorias.

Las elevadas expansiones iníciales de los hormigones fueron también observadas en el trabajo de Li (2005) sobre la mitigación de la RAS en HAR. N o obstante, lo dicho autor comenta que las expansiones son más evidentes en los ensayos con hormigones que con morteros, lo que justifica con el pequeño tamaño de las partículas.

La metodología de ejecución del ensayo acelerado de la barra de mortero fue modificada por al-gunos investigadores como Li (2005), Scott (2006), Etxeberria (2004) o Shehata et al. (2008) en-tre otros, para testar la reactividad del AR. Los dichos investigadores consideran que el ensayo de la barra de mortero para testar la reactividad de los AR se debe hacer separadamente al árido y al mortero adherido que constituye el AR. La polvorización del mortero adherido, durante la reduc-ción del árido para introducción en la mezcla, altera las características del conjunto de los AR.

Shehata et al. (2008) consideran también que en el ensayo acelerado de la barra de mortero se de-ben utilizar los AR finos provenientes de la trituración secundaria, es decir, de los AR gruesos. Se observaron diferencias en los valores de la expansión de los morteros producidos con AR finos de la trituración primaria del hormigón de origen y de la trituración secundaria de los AR gruesos. En su investigación, verificaron igualmente la existencia de la reactividad en HAR producido con AR provenientes de HAP afectado por la RAS. Estos autores creen que la reactividad hallada en el HAR fue potenciada con la trituración del HAP, produciendo nuevas faces frescas de contacto entre los AP reactivos y el nuevo cemento de la mezcla, causando expansiones en el nuevo hor-migón.

\section{Conclusiones}

Se ha verificado que los ensayos de moteros para evaluación de la RAS, aunque más céleres, pueden suscitar variaciones de resultados debido a la fragmentación del $A R$, para el ensayo, que provoca la pulverización del mortero adherido, creando AR fino con características distintas del AR grueso original. Algunos estudios presentados recomiendan que se ensaye separadamente el mortero adherido y el AP, constituyentes del AR,
According to his conclusions, this researcher considers that tests on ASR in CRA should be focused on the material characteristics, including absorption, mortar fraction and alkali-free rates. He also comments that results for modified tests showed satisfactory correlations, however, he suggested to continuing to follow up some cases.

High initial expansions in concrete were also studied by Li (2005) concerning ASR mitigation in CRA. However, this author indicates that expansions are clearer in the concrete tests than in mortar tests, which is explained by the small size of particles.

The methodology for the execution of the accelerated mortar bar method was modified by some researchers as Li (2005), Scott (2006), Etxeberria (2004) or Shehata et al. (2008), among others, in order to test the RA reactivity. Such researchers consider that in order to test the AR reactivity, the mortar bar method must be applied separately to the aggregate and to the adhered mortar contained in the RA. The adhered mortar pulverizing, changes the characteristics of the RA during aggregate reduction, before pouring it into the mixture.

Shehata et al. (2008) also consider that the accelerated bar mortar method should also include the fine RA resulting from secondary crushing, that is from coarse RA. Differences were found in relation to mortar expansion values for fine RA resulting from original concrete primary crushing and resulting from coarse RA secondary crushing process. The research also confirmed the presence of reactivity in CRA produced with RA coming from CRA affected by ASR. These authors believe that reactivity found in CRA was strengthen by CNA crushing, thus allowing new contact fresh phases between reactive NA and the new cement in the mixture, causing expansions in the new concrete.

\section{Conclusions}

It has been found out that some mortar tests for the evaluation of ASR, even though faster, may result in changes in the results due to the fragmentation of RA for testing that leads to pulverizing the adhered mortar and creating fine RA with different characteristics from those of the original coarse RA. Some studies presented recommend developing separate tests for adhered mortar and for NA, contained in RA, 
o que únicamente se utilice para el ensayo el $A R$ resultante de trituración de $A R$, es decir, de una trituración secundaria. Existen también pro-puestas de modificación del ensayo acelerado ASTM C 1260 para el caso del AR empleando probetas de hormigón para evitar alteraciones en las características del AR grueso.

Debido a la absorción de agua del AR, algunos artículos recomiendan su presaturación para evitar variaciones significativas en los resultados de expansión de probetas de hormigón a edades pre-maturas. otherwise only RA, resulting from a secondary crushing process should be used. There are also proposals to modify the accelerated ASTM C 1260 test for RA by using concrete specimens that would avoid alteration of coarse RA characteristics.

Due to water absorption by RA, some articles recommend pre-saturation to avoid significant variations for expansion results on concrete specimens at early ages.

\section{Referencias / References}

Alaejos P., Sánches M., Dapena E., Vásquez E., Barra M, Etxeberria M., Marí A., Agullo L., Marínez F., Fonteboa B., Polanco

A., Francisco G., Aleza F., Parra J., Buron M. (2004), "D raft of Spanish regulations for the use of recycled aggregate in the production of structural concrete", International RILEM Conference on the use of recycled materials in buildings and structures, Barcelona, pp. 511-525

Alaejos P., Sánchez M. (2004), "Utilization of recycled concrete aggregate for structural concrete”, International RILEM Conference on the use of recycled materials in buildings and structures, Barcelona, pp. 693-712

ASTM C 1293 (2004), "Standard test method for determination of length change due to alkali-silica reaction", The American Society for Testing and Materials, Philadelphia, $6 \mathrm{p}$.

ASTM C 150-02 (2003), "Standard specification for portland cement". The American Society for Testing and Materials, Philadelphia, 7 p. ASTM C1260 (1994), "Standard test method for potential alkali reactivity of aggregates (mortar bar method)", American Society for Testing and Materials Brito J. de (2005), "Agregados reciclados e sua influência nas propriedades dos betões", Lição de Síntese de Agregação em Engenharia Civil, Instituto Superior Técnico, Universidade Técnica de Lisboa, Lisboa, Março

Carrijo P. M. (2005), “Análise da influência da massa específica de agregados graúdos provenientes de resíduos de construção e demolição no desempenho mecânico do concreto", Dissertação de Mestrado em Engenharia Civil, Escola Politécnica, Universidade de São Paulo, São Paulo

Chatterji S. (1989), "M echanisms of Alkali-Silica reaction and expansion”, Proceedings of $8^{\text {th }}$ International Conference on Alkali-Aggregate Reaction, Kyoto, Japan, pp. 101-105.

Dent Glasser L. S., Kataoka N. (1981), “Some observations on the rapid chemical test for potentially reactive aggregate”, Cement and Concrete Research, Vol. 11, n.․․ 2, pp. 191-196

Dent Glasser L. S., Kataoka N. (1981), "The chemistry of "alkali-aggregate" reaction", Cement and Concrete Research, Vol. 11 , n.o 1, pp. 1-9

Etxeberria M. (2004), "Experimental study on microstructure and structural behaviour of recycled aggregate concrete", Tese de Doctorado en Ingeniería Civil, Universidad Politécnica da Cataluña, Barcelona

Evangelista L. (2007), "Desempenho de betões executados com agregados finos reciclados de betão", Dissertação de Mestrado em Construção, Instituto Superior Técnico, U niversidade Técnica de Lisboa, Lisboa

Fernandes M. I. G. (2005), “Caracterização petrográfica, química e física de agregados graníticos em betões. Estudo de casos de obra”, Tese de D outoramento em Geologia, Faculdade de Ciências da Universidade do Porto, Porto

Gress D. L., Kozikowski R. L. (2000), "Accelerated ASR testing of concrete prisms incor-porating recycled concrete aggregate", Proceedings of the $11^{\text {th }}$ International Conference on Alkali-Aggregate Reaction in Concrete, Q uebec City, Q C, Canada, June, pp. 1139-1148

Hansen T. C. (1992), "Recycling of demolished concrete and masonry", RILEM Report 6, London \& FN SPON imprint of Chapman \& Hall Hoobs D. W. (1988), "Alkali-silica reaction in concrete", Thomas Telford Ltd., London, 183 p.

Kozikowski jr. R.L. (2000), "Accelerated ASR testing of concrete using recycled aggregates", Master's Thesis, University of New Hampshire

Levy S. M. (2001), "Contribuição ao estudo da durabilidade de concretos, produzidos com resíduos de concreto e alvenaria", Tese de D outoramento em Engenharia Civil, Escola Politécnica da U niversidade de São Paulo, São Paulo, Dezembro

Li Xinghe (2005), "Mitigating alkali silica reactions in recycled concrete", Doctoral Thesis in Civil Engineering, University of New Hampshire, December

LNEC E 461 (2006), "Betões. Metodologias para prevenir reacções expansivas internas", Laboratório Nacional de Engenharia Civil, Lisboa, 6 p.

Matias D., Brito J. de (2005), "Influência dos adjuvantes no desempenho de betões com agregados grossos reciclados de betão", Relatório ICIST DTC n. $3 / 05$, Instituto Superior Técnico, Lisboa

Miranda L.F.R. (2000), “Estudo de factores que influem na fissuração de revestimentos de argamassas com entulho reciclado", Dissertação de M estrado, Escola Politécnica, U niversidade de São Paulo, São Paulo

Pecchio M., Kihara Y., Battagin A. F. y Andrade T. (2006), "Produtos da reacção álcalis-silicato em concretos de edificações da região do Grande Recife - PE", II Simpósio sobre Reacção Álcalis-agregado em Estruturas de Concreto, RAA 2006, IBRAN CO N, 10 p.

Prince W., Perami R. (1993), “M ise en évidence du rôle essential des ions OH- dans les ré-actions alcalis-silice”, Cement and Concrete Research, Vol. 23(5), pp. 1121-1129

Santos J. R., Brito J. de, Gonçalves A. P. y Branco F. A. (2002),"Campanha experimental efectuada no IST", Seminário "Betão para a Construção Sustentável", APEB, Lisboa

Santos Silva A. (2006), "D egradação do betão por reacções álcalis-sílica - U tilização de cinzas volantes e metacaulino para a sua prevenção”, Tese de D outoramento em Engenharia Civil pela Escola de Engenharia da Universidade do M inho, Teses e Programas de Investigação, Laboratório Nacional de Engenharia Civil, 339 p., Lisboa

Santos Silva A. (2007), "Reacções expansivas no betão", Seminário “Em ambiente marinho", Funchal

Scott H. C. (2006), "Mitigating alkali silicate reaction in recycled concrete", Master Thesis in Civil Engineering, U niversity of New Hampshire, March

Shehata M., Christidis C., Mikhaiel W., Rogers C. y Lachemi M. (2008), "Re-activity of reclaimed concrete aggregate produced from concrete affected by alkali silica reaction", Proceedings of 13th International Conference on Alkali-Aggregate Reaction in Concrete, Trond-heim, Norway, pp. $1230-1239$

Stievenard-Gireaud D. (1987), “Étude de la réaction alcalis-silice dans dès bétons”, Labo-ratoire Central dès Ponts et Chaussées, Rapport de recherche LPC n. 144, Paris, $104 \mathrm{p}$.

TR 3 - Technical Report 3 (2003), "Alkali silica reaction - Minimizing the risk of damage to con-crete, guidance notes and recommended practice", Cement and Concrete Association of $\mathrm{New}$ Zea-land, $84 \mathrm{p}$. 